\title{
Cetraria steppae Savicz is conspecific with Cetraria aculeata (Schreb.) Fr. according to morphology, secondary chemistry and ecology
}

\section{Olga NADYEINA, Tetiana LUTSAK, Oleg BLUM, Volodymyr GRAKHOV and Christoph SCHEIDEGGER}

\begin{abstract}
Eurasian Cetraria steppae and the more widely distributed C. aculeata are two lichen species traditionally distinguished by Eastern European and Spanish lichenologists on the basis of their morphological and ecological characteristics. Other specialists, however, consider them puzzling. This paper aims to evaluate the taxonomic status of these members of the $C$. aculeata group and thereby to clarify their conservation status in Ukraine. Morphological, chemical and ecological features of specimens originating from populations in different regions of Ukraine were tested and compared with the main characteristics commonly used for the species delimitation. Neither morphological nor chemical traits were found to correlate with ecological characteristics on a small geographical scale. Variation in the norstictic acid content detected in 256 individuals from 13 populations in Ukraine showed no correlation with the morphological characteristics that are currently used for species delimitation. These morphological features appear to vary continuously and did not support subdivision among the specimens studied. We hypothesize that $C$. steppae and $C$. aculeata are conspecific, and provide a formal synonymy. Specimens with norstictic acid are regarded as a different chemotype. Possible evolutionary and adaptive roles of norstictic acid in C. aculeata s. lat. are discussed. Based on current and historical data, we consider C. aculeata s. lat. as vulnerable in Ukraine, according to the IUCN criteria for regional Red List assessment.
\end{abstract}

Key words: IUCN, lichens, norstictic acid, populations, Red Data Book, Red List, Ukraine

\section{Introduction}

Members of the Cetraria aculeata group are fruticose, brownish black lichens and they include C. aculeata (Schreb.) Fr., $C$.

O. Nadyeina: M. G. Kholodny Institute of Botany, Lichenology and Bryology Department, Kyiv, Ukraine; and Biodiversity and Conservation Biology, Swiss Federal Institute for Forest, Snow and Landscape Research (WSL), Birmensdorf, Switzerland. Email: nadyeina@gmail.com T. Lutsak: Taras Shevchenko National University of Kyiv, Department of Botany, Kyiv, Ukraine; and Senckenberg Research Institute and Natural History Museum, Frankfurt on Main, Germany.

O. Blum: M. M. Gryshko National Botanical Garden of the Academy of Science of Ukraine, Bioindication and Chemosystematics Laboratory, Kyiv, Ukraine.

V. Grakhov: M. M. Gryshko National Botanical Garden of the Academy of Sciences of Ukraine, HPLC Center, Kyiv, Ukraine.

C. Scheidegger: Biodiversity and Conservation Biology, Swiss Federal Institute for Forest, Snow and Landscape Research (WSL), Birmensdorf, Switzerland. australiensis W. A. Weber ex Kärnefelt, $C$. crespoae (Barreno \& Vázquez) Kärnefelt, $C$. muricata (Ach.) Eckfeldt, C. odontella (Ach.) Ach., 'C. panamericana' and C. steppae (Savicz) Kärnefelt (Kärnefelt et al. 1992; Thell et al. 2002; Printzen et al. 2013). Of these, $C$. aculeata and $C$. steppae have been considered as two closely related species (Savicz 1924; Kärnefelt 1986; Kärnefelt et al. 1993). Cetraria aculeata s. lat. was the subject of special taxonomic and phylogenetic studies (Kärnefelt 1986; Kärnefelt et al. 1992, 1993; Thell et al. 2000, 2002; Printzen et al. 2013). The phylogeography of its symbionts has been investigated (Fernández-Mendoza et al. 2011; Domaschke et al. 2012; Printzen et al. 2013; Fernández-Mendoza \& Printzen 2013), as well as the anatomy and ecophysiology of extreme morphotypes (Pérez-Ortega et al. 2012), and the bacterial communities within geographically distinct populations (Printzen 
TABLE 1. Features used for the delimitation of C. aculeata and C. steppae according to Savicz's (1924) and Kärnefelt's (1986) descriptions.

\begin{tabular}{|c|c|c|c|}
\hline Character & $\begin{array}{c}\text { Cetraria aculeata } \\
\text { (Schreb.) } \\
\text { Fr. }\end{array}$ & $\begin{array}{l}\text { Cetraria steppae (Savicz) } \\
\text { Kärnefelt }\end{array}$ & Reference \\
\hline \multirow[t]{2}{*}{ Thallus vagrancy } & Attached tufts & $\begin{array}{l}\text { Different mode of life } \\
\text { from C. aculeata }\end{array}$ & Savicz 1924 \\
\hline & $\begin{array}{l}\text { Branches forming } \\
\pm \text { shrubby tufts, which } \\
\text { arise directly from the } \\
\text { substratum; also tends } \\
\text { to develop spherical } \\
\text { thalli, composed of } \\
\text { more branches than } \\
\text { thalli of } C \text {. steppae }\end{array}$ & $\begin{array}{l}\text { Branches forming } \\
\pm \text { spherical tufts com- } \\
\text { posed of a few branches } \\
\text { due to the vagrant mode } \\
\text { of life }\end{array}$ & Kärnefelt 1986 \\
\hline \multirow[t]{2}{*}{$\begin{array}{l}\text { Thallus specific } \\
\text { features }\end{array}$} & $\begin{array}{l}\text { Glossy, solid, inflexible, } \\
\text { fragile }\end{array}$ & $\begin{array}{l}\text { Matt, smooth, soft and } \\
\text { flexible, not fragile }\end{array}$ & Savicz, 1924 \\
\hline & \multicolumn{2}{|c|}{$\begin{array}{l}\text { Glossy to matt; black, brown to light brown; varying } \\
\text { fragility }\end{array}$} & Kärnefelt 1986 \\
\hline \multirow[t]{2}{*}{ Thallus size } & \multicolumn{2}{|c|}{ Not indicated } & Savicz 1924 \\
\hline & $2-4(-10) \mathrm{cm}$ high & $1-3 \mathrm{~cm}$ high & Kärnefelt 1986 \\
\hline \multirow[t]{2}{*}{ Branch size } & $\begin{array}{l}\text { Long and thin: } \\
0 \cdot 3-1.0 \mathrm{~mm} \text { wide }\end{array}$ & $\begin{array}{l}\text { Short and thick: } \\
0 \cdot 4-2 \cdot 0 \mathrm{~mm} \text { wide }\end{array}$ & Savicz 1924 \\
\hline & $\begin{array}{l}\text { Main branches } c .1(-4) \\
\text { mm wide; terminal } \\
\text { branches } c .0 \cdot 3-1 \cdot 0 \mathrm{~mm} \\
\text { wide }\end{array}$ & $\begin{array}{l}\text { Main branches } c .0 \cdot 5- \\
2 \cdot 0(-4 \cdot 0) \text { mm wide; } \\
\text { terminal branches } \\
\text { c. } 0 \cdot 1-5 \cdot 0 \mathrm{~mm} \text { wide }\end{array}$ & Kärnefelt 1986 \\
\hline \multirow[t]{2}{*}{ Isidioid projections } & Tiny, rarely present & Absent & Savicz 1924 \\
\hline & \multicolumn{2}{|c|}{ Absent or present } & Kärnefelt 1986 \\
\hline \multirow[t]{2}{*}{ Chemistry } & $\mathrm{K}-$ & $\mathrm{K}-, \mathrm{C}-, \mathrm{I}-$ & Savicz 1924 \\
\hline & $\begin{array}{l}\text { K-; norstictic acid } \\
\text { absent (TLC) }\end{array}$ & $\begin{array}{l}\text { K+; norstictic acid } \\
\text { present (TLC) }\end{array}$ & Kärnefelt 1986 \\
\hline
\end{tabular}

et al. 2012). However, the taxonomic status of $C$. steppae as a distinct species has been questioned (Fernández-Mendoza et al. 2011; Lutsak et al. 2012) as its morphology varies greatly and its distribution range overlaps with that of $C$. aculeata (Poelt 1969; Randlane \& Saag 2006).

Distinguishing Cetraria steppae and C. aculeata as distinct species was traditionally based on visual morphological aspects (Savicz 1924; Oxner 1937; Poelt 1969), which include a vagrant mode of life, the surface characteristics of the thalli and morphological parameters of the main and terminal branches (Table 1).
Mereschkowsky was the first to pay attention to vagrancy and the small number of branches among specimens from Crimea (Ukraine). His description is, however, very brief: "Thallus libertus, opacus, laciniis paullulum minus attenuatis" (Mereschkowsky 1921). The author of C. steppae at the species level is Savicz, who also gave a concise description (Table 1). He emphasized that both taxa are distinct species without intermediate forms, which implied that $C$. steppae occurs in the southern steppe biotopes and $C$. aculeata in the north (Savicz 1924). This statement guided lichenologists to distinguish the two species, when 
the vagrant mode of life or the thickness of branches were not well developed. In the 1980s, Kärnefelt performed a wide-scale survey of the brown Cetraria species (Kärnefelt 1986) and revised the traits for morphological distinction of the two species. He introduced a new feature, the presence of norstictic acid in $C$. steppae, which was not considered in the original description of $C$. steppae (Savicz 1924; Table 1) and became crucial for the delimitation of the two species. Moreover, Kärnefelt extended the concept of $C$. steppae and also included specimens with isidioid projections and black, glossy thalli (Table 1). After being described by Savicz (1924), the species was reported in other parts of southern Ukraine (Oxner 1937, 1993; Blum 1996; Blum et al. 2009) and Russia (Zhurbenko 1996; Moutchnik \& Zavarzin 2005; Golubkova et al. 2008; Urbanavichus 2010), Kazakhstan (Wagner \& Spribille 2005), Turkey (John 1999; John \& Breuss 2004; Yaz1c1 et al. 2010), Iran (Sohrabi \& Alstrup 2007; Seaward et al. 2008), and Spain (Llimona \& Hladun 2001).

In our analysis of 247 herbarium specimens of $C$. aculeata s. lat., we were not able to classify all specimens as belonging to one or other of the two taxa because of contradictions or uncertainties in diagnostic traits (Table 1). The features traditionally used to distinguish them seemed to be quite subjective, such as the degree of vagrancy or the thickness of the branches. The vagrant life form and spherical tuft-like thalli are often difficult to designate, both on herbarium specimens and in the field. Specimens kept in herbaria are usually carefully separated, and could look 'artificially vagrant' (Fig. 1A \& C). In the field, the recognizable vagrant thalli grow on bare soil or sand. However, a few centimetres away, individuals may often be attached, which changes their degree of vagrancy (Fig. 1B \& D). Delimitation of individuals is also contentious because thalli in vagrant tufts or in mostly attached mats are often densely entangled (Fahselt 2008).

The above-mentioned difficulties motivated us to check the morphological variability within and between populations sampled from different regions in Ukraine. The present study aimed to test characters tradition- ally used for the delimitation of $C$. steppae and $C$. aculeata, and to elucidate their taxonomic value. We also wanted to study the impact of ecological and geographical factors on the morphological and chemical characteristics within this group. We hypothesized that specimens belonging to C. steppae contain norstictic acid in the medulla (Kärnefelt 1986), have wider thallus branches, smaller thalli, a vagrant lifestyle, and a distribution limited to the south of Ukraine (Savicz 1924). The aim was also to test the correlation between the presence of norsticitic acid and the content of carbonates in the substrata of arid areas (Hauck et al. 2010). Finally, we assess and discuss the conservation status of C. aculeata s. lat. according to the IUCN Red List criteria for the next edition of the Red Data Book of Ukraine.

\section{Materials and Methods}

\section{Materials and sampling design}

A total of 503 specimens of $C$. aculeata s. lat. from Ukraine were studied. First, we examined 247 specimens from different herbaria (KW, KHER, LE), according their morphological, chemical and ecological characteristics (Fig. 1E). We then collected 256 specimens from 13 local populations, representing different natural zones of Ukraine during 2010-2011. Their characteristics are summarized in Table 2 and locations shown in Fig. 1E. All specimens were classified a priori as Cetraria aculeata s. lat. A tuft $c .5-10 \mathrm{~cm}^{2}$ was considered to be one specimen ('thallus'). To analyze the chemical variability among neighbouring thalli (which are probably vegetative clones), we sampled thalli at 0.5 $\mathrm{m}$ intervals along transects $10-25 \mathrm{~m}$ in length and $0.5 \mathrm{~m}$ in width within each population. As a result, 5-41 specimens per population were collected according to their availability, amounting to 256 thalli in total. To study the morphological variability within the local populations, we selected a subset of 122 specimens, sampled at distances of $>1 \mathrm{~m}$ along the same transects, resulting in 5-18 specimens per population (Table 2 ). Because the species reproduces only asexually in Ukraine (no specimens with fruit bodies have been found so far in this area), we selected $1 \mathrm{~m}$ as the minimum distance to reduce the clones in our dataset because the range of dispersal through thallus fragments is considered to be less than $1 \mathrm{~m}$ (Heinken 1999).

\section{Morphological study}

A subset of 122 air-dried specimens, collected from the 13 local populations mentioned above, was selected for morphometric measurements (Tables $2 \& 3$ ). For each specimen, we measured the size of the whole thallus, 

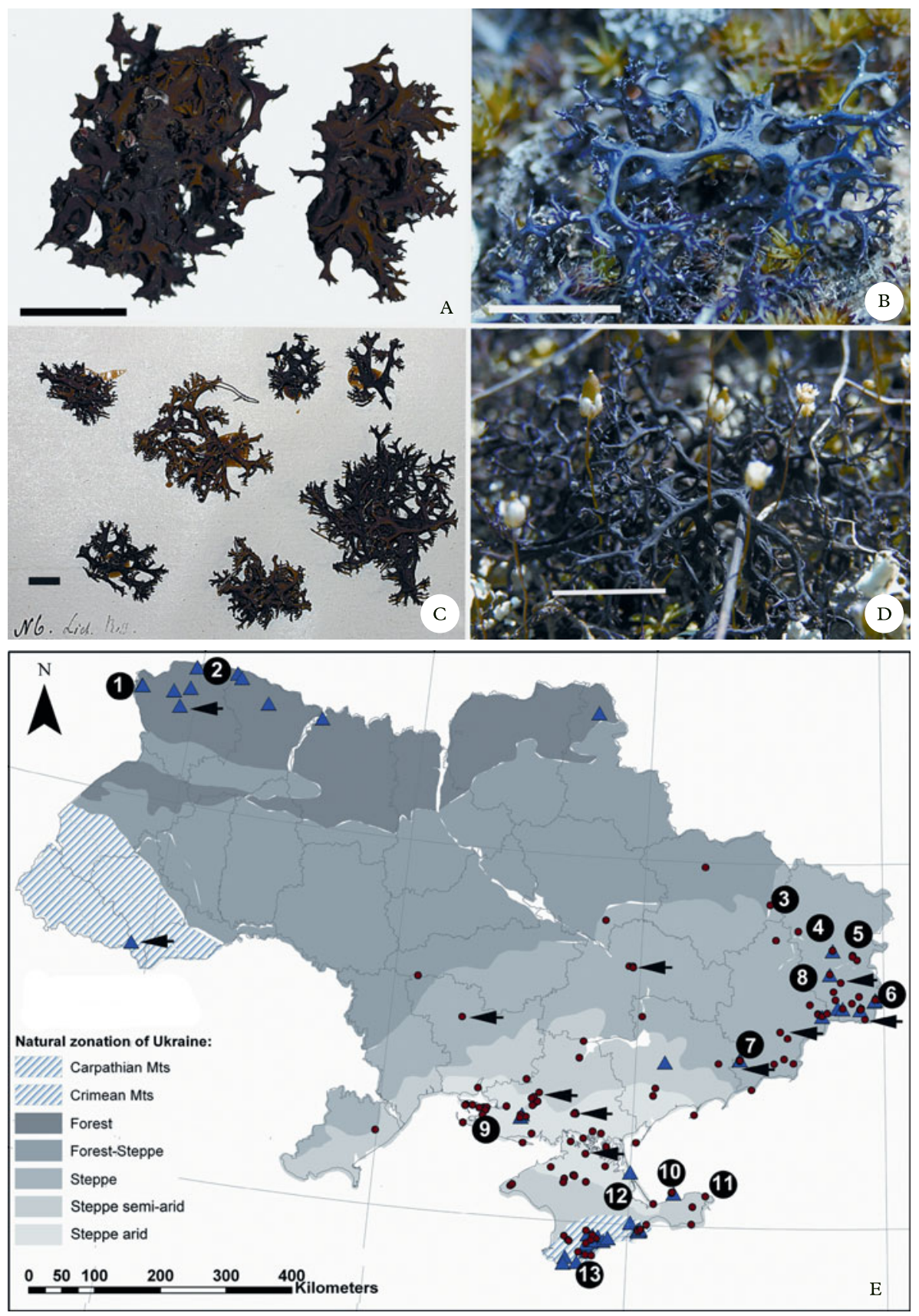

FIg. 1. Morphological diversity and distribution of Cetraria aculeata s. lat. A, Crimea, Dzhankoj region, norstictic acid minor; B, Luhansk region, norstictic acid minor; C, type specimen (LE 220), Kherson region, norstictic acid major; D, Donetsk region, norstictic acid major; E, distribution in Ukraine, based on the analysis of 247 specimens (KW, KHER, LE) tested by TLC, numbers correspond to the sampling sites of the populations given in Table 2. Arrows indicate specimens selected for HPLC analysis (listed in Table 4); red circles, norstictic acid present; blue triangles, norstictic acid absent. Scales: $A-D=1 \mathrm{~cm}$. 
TABle 2. Populations of Cetraria aculeata s. lat. examined with characteristics of their sites (natural zones of Ukraine: $F$ - polissia (forest), FS - forest-steppe, $S$-steppe, SSA - steppe semi-arid, SA - steppe arid, CM - Crimean Mountains; Habitats: $O$ - open places, clearings among pine forest plantation, $G$ - grasslands and heaths, $Y$ - yayla or mountain top, deforested by grazing).

\begin{tabular}{|c|c|c|c|c|c|c|c|}
\hline $\begin{array}{l}\text { Site } \\
\text { No. }\end{array}$ & Population & $\begin{array}{c}\text { Altitude, } \\
\text { m a.s.l. }\end{array}$ & $\begin{array}{l}\text { Natural } \\
\text { zone of } \\
\text { Ukraine }\end{array}$ & Habitat & Substratum & $\begin{array}{l}\text { Number of } \\
\text { specimens } \\
\text { selected for } \\
\text { morphometric } \\
\text { study } \\
(n=122)\end{array}$ & $\begin{array}{c}\text { Total number } \\
\text { of specimens } \\
\text { analyzed } \\
\text { (including TLC, } \\
n=256 \text { ) }\end{array}$ \\
\hline 1 & Shatsk* & 170 & $\mathrm{~F}$ & $\mathrm{O}$ & Sand & 11 & 41 \\
\hline 2 & Ratno & 145 & $\mathrm{~F}$ & $\mathrm{O}$ & Sand & 5 & 12 \\
\hline 3 & Platonivka & 90 & FS & $\mathrm{O}$ & Sand & 9 & 16 \\
\hline 4 & Trehizbenka** & 107 & $\mathrm{~S}$ & G & Sand & 10 & 25 \\
\hline 5 & Stanychno-Luhansk** & 55 & $\mathrm{~S}$ & $\mathrm{O}$ & Sand & 10 & 20 \\
\hline 6 & Provallia** & 170 & $S$ & $\mathrm{O}$ & Soil & 10 & 21 \\
\hline 7 & Kamjany Mohyly $\dagger$ & 160 & $S$ & $\mathrm{O}$ & Granite & 14 & 22 \\
\hline 8 & Antratsit & 140 & $\mathrm{~S}$ & $\mathrm{O}$ & Soil & 6 & 15 \\
\hline 9 & Burkuty & 15 & SA & G & Sand & 15 & 5 \\
\hline 10 & Kazantyp & 10 & SSA & G & Limestone & 11 & 23 \\
\hline 11 & Bondarenkovo & 55 & SSA & G & Soil & 7 & 14 \\
\hline 12 & Arabat Split & 0 & SA & G & Sand & 6 & 11 \\
\hline 13 & Chatyr Dag & 1340 & $\mathrm{CM}$ & $\mathrm{Y}$ & Limestone & 18 & 21 \\
\hline
\end{tabular}

* Shatsk Lakes National Nature Park; ** Branch of Luhansk Steppe Nature Reserve; † Branch of Ukrainian Nature Steppe Reserve; $\$$ Kazantyp Nature Reserve; $₫$ Arabat Split Botanical Reserve.

the width of the main branches at the basal bifurcations, and the width of terminal branches below the last bifurcation (Table 3). Five measurements of each trait per specimen were performed. The morphometric measurements are presented as (min-) mean \pm Standard Deviation $(-\max )$. The presence or absence of isidioid projections was recorded for each specimen (Table 3 ).

\section{Chemical analyses}

Each of the 247 herbarium specimens was tested by spot reactions with $10 \%$ aqueous solution of potassium hydroxide $(\mathrm{K})$ and dissolved crystals of paraphenylenediamine in ethanol (Pd). The lichen substances were also analyzed using the microcrystal test method (Orange et al. 2001) for a subset of 17 selected specimens (Table 4).

Each of the 503 specimens studied were also analyzed by thin-layer chromatography (TLC), according to standard protocols (White \& James 1985; Orange et al. 2001) using Sorbifil UV plates (Russia) and solvent A.

High performance liquid chromatography (HPLC) was applied to a subset of 17 specimens, which were selected according to the following criteria: 1) specimens originating from different parts of Ukraine (the Carpathians, north-west, south-east and south Ukraine, including Crimea); 2) individuals originating from localities where, according to the TLC analysis, specimens with and without norstictic acid were present. Localities for specimens analyzed by HPLC are indicated in Fig. 1E with arrows and listed in Table 4. HPLC analyses were carried out on the basis of methods described in Yoshimura et al. (1994), Gupta et al. (2007) and Manojlović et al. (2010). The content of the lichen substances was quantified according to a 10-point scale using peak heights at $224 \mathrm{~nm}$ and $1000 \mathrm{mAU}$ detector signal range for each specimen. A peak height between 500-1000 mAU was considered as "major" (5-10 points), 300$500 \mathrm{mAU}$ as "medium" (3-5 points), $30-300 \mathrm{mAU}$ as "minor" (1-3 points) and less than $30 \mathrm{mAU}$ as "traces" (1 point).

\section{Statistical analyses}

Basic statistics for the morphometric parameters of the C. aculeata s. lat. specimens collected from all 13 populations, an analysis of variance (ANOVA) and the principal component analysis (PCA) were run in JMP 9 (SAS Institute Inc., Cary, North Carolina). The coefficient of variation $(\mathrm{CV})$ was calculated for the entire dataset and each population (Table 3). Values of CV were classified in five categories: minor variation $(0-10 \%)$, little variation $(11-20 \%)$, average variation $(21-40 \%)$, high variation $(41-60 \%)$ and very high variation $(61-100 \%)$. To 
TABLE 3. Morphometric $(\mathrm{n}=122)$ and chemical $(\mathrm{n}=256)$ characteristics of the populations of $\mathrm{C}$. aculeata s. lat. studied.

\begin{tabular}{|c|c|c|c|c|c|c|c|c|c|}
\hline \multirow[b]{2}{*}{ Site No. } & \multirow[b]{2}{*}{ Population } & \multicolumn{2}{|c|}{$\begin{array}{l}\text { Width of the } \\
\text { main branch (mm) }\end{array}$} & \multicolumn{2}{|c|}{$\begin{array}{l}\text { Width of the } \\
\text { terminal branch (mm) }\end{array}$} & \multicolumn{2}{|c|}{ Thallus size $(\mathrm{mm})$} & \multirow[b]{2}{*}{$\begin{array}{l}\text { Thalli with isidioid } \\
\text { projections, } \%\end{array}$} & \multirow[b]{2}{*}{$\begin{array}{l}\text { Thalli with norstictic } \\
\text { acid, } \%\end{array}$} \\
\hline & & Mean \pm SD & $\mathrm{CV}, \%$ & Mean \pm SD & $\mathrm{CV}, \%$ & Mean \pm SD & $\mathrm{CV}, \%$ & & \\
\hline 1 & Shatsk & $1 \cdot 29 \pm 0 \cdot 16$ & $12 \cdot 45$ & $0.47 \pm 0.08$ & $16 \cdot 00$ & $3 \cdot 27 \pm 1 \cdot 26$ & $38 \cdot 42$ & 36 & 0 \\
\hline 2 & Ratno & $1.51 \pm 0.28$ & $18 \cdot 19$ & $0 \cdot 40 \pm 0 \cdot 10$ & $24 \cdot 85$ & $6 \cdot 43 \pm 2 \cdot 00$ & 31.05 & 60 & 0 \\
\hline 3 & Platonivka & $1.44 \pm 0.36$ & $24 \cdot 63$ & $0.48 \pm 0.06$ & 12.92 & $3.57 \pm 1.06$ & $29 \cdot 64$ & 100 & 100 \\
\hline 4 & Trehizbenka & $1 \cdot 15 \pm 0 \cdot 23$ & $20 \cdot 37$ & $0.46 \pm 0.06$ & $13 \cdot 41$ & $3 \cdot 20 \pm 0 \cdot 74$ & $23 \cdot 23$ & 30 & 100 \\
\hline 5 & Stanychno-Luhansk & $1.20 \pm 0.35$ & $29 \cdot 40$ & $0 \cdot 50 \pm 0 \cdot 10$ & $20 \cdot 23$ & $3 \cdot 21 \pm 0.38$ & 11.96 & 20 & 90 \\
\hline 6 & Provallia & $1.57 \pm 0 \cdot 17$ & $10 \cdot 81$ & $0.50 \pm 0.03$ & $6 \cdot 82$ & $2 \cdot 26 \pm 0 \cdot 60$ & $26 \cdot 50$ & 10 & 80 \\
\hline 7 & Kamjany Mohyly & $1.62 \pm 0.34$ & $20 \cdot 84$ & $0.50 \pm 0.03$ & $6 \cdot 08$ & $4 \cdot 33 \pm 1 \cdot 19$ & $27 \cdot 43$ & 43 & 64 \\
\hline 8 & Antratsit & $1.56 \pm 0 \cdot 16$ & $10 \cdot 36$ & $0.50 \pm 0.05$ & $10 \cdot 00$ & $2 \cdot 92 \pm 0 \cdot 26$ & $8 \cdot 85$ & 100 & 17 \\
\hline 9 & Burkuty & $1 \cdot 25 \pm 0 \cdot 26$ & $21 \cdot 13$ & $0.44 \pm 0.08$ & $18 \cdot 13$ & $4 \cdot 47 \pm 1 \cdot 21$ & $27 \cdot 00$ & 40 & 100 \\
\hline 10 & Kazantyp & $1.32 \pm 0.23$ & $17 \cdot 76$ & $0.53 \pm 0.06$ & 11.93 & $4 \cdot 19 \pm 1.38$ & 32.92 & 64 & 73 \\
\hline 11 & Bondarenkovo & $1.41 \pm 0.37$ & $26 \cdot 34$ & $0.50 \pm 0.02$ & $4 \cdot 89$ & $3.40 \pm 0.92$ & $27 \cdot 04$ & 29 & 100 \\
\hline 12 & Arabat Split & $1.75 \pm 0.25$ & $14 \cdot 42$ & $0.55 \pm 0.06$ & $10 \cdot 64$ & $3 \cdot 05 \pm 0.45$ & $14 \cdot 77$ & 0 & 100 \\
\hline \multirow[t]{2}{*}{13} & Chatyr Dag & $1.28 \pm 0.30$ & 23.56 & $0.47 \pm 0.06$ & $12 \cdot 15$ & $4.45 \pm 0.90$ & $20 \cdot 18$ & 100 & 22 \\
\hline & Total in the dataset & $1.39 \pm 0.32$ & $22 \cdot 74$ & $0.49 \pm 0.07$ & $13 \cdot 81$ & $3.73 \pm 1.31$ & 34.99 & 52 & 62 \\
\hline
\end{tabular}


TABLE 4. HPLC study of selected specimens of C. aculeata s. lat. from Ukraine

\begin{tabular}{|c|c|c|c|}
\hline Herbarium No. & Locality, collector, year & TLC data* & HPLC data** \\
\hline LE220 (Type) & Kherson reg., Chaplynsky distr. Oxner, 1923 & NST, L & NST (8), L (2), PL (1) \\
\hline KW5770 & Kherson reg., Hola Pristan distr. Makarevych, 1950 & NST, L, PL & NST (4), L (4), PL (2) \\
\hline KW65049 & Kherson reg., Bilozerka distr. Nadyeina, 2010 & NST, L & NST (3), L (5), PL (1) \\
\hline KW5824 & Crimea, Dzhankoi reg. Osmanova, 1932 & NST, L, PL & NST (9), L (6), PL (2) \\
\hline KW66928 & Luhansk reg., Sverdlovsk distr. Vasyluk, 2010 & $\mathrm{~L}, \mathrm{PL}$ & NST (2), L (3), PL (1) \\
\hline KW66930 & Luhansk reg., Sverdlovsk distr. Vasyluk, 2010 & NST, L & NST (2), L (8) \\
\hline KW64472 & Luhansk reg., Sverdlovsk distr. Nadyeina, 2005 & $\mathrm{~L}$ & NST (1), L (6) \\
\hline KW64477 & Luhansk reg., Sverdlovsk distr. Nadyeina, 2005 & NST, L & NST (2-3), L (3), PL (1) \\
\hline KW5855 & $\begin{array}{l}\text { Donetsk reg., Volodarsk distr. Oxner } \mathcal{E} \\
\text { Kopachevska, } 1954\end{array}$ & L, PL & NST (1), L (5), PL (1) \\
\hline KW5856 & $\begin{array}{l}\text { Donetsk reg., Volodarsk distr. Oxner } \mathcal{E} \\
\text { Kopacherska, } 1954\end{array}$ & NST, L & NST (1), L (4), PL (1) \\
\hline KW64475 & Donetsk reg., Shakhtarsk distr. Nadyeina, 2006 & $\mathrm{~L}, \mathrm{PL}$ & NST (2), L (6) \\
\hline KW64476 & Donetsk reg., Shakhtarsk distr. Nadyeina, 2006 & NST & NST (9) \\
\hline KW33190 & $\begin{array}{l}\text { Kyrovograd reg., Holovanivka distr. } \\
\text { Kondratyuk, } 1983\end{array}$ & NST, L & NST (10) \\
\hline KW27645 & Mykolaiv reg., Bratsk distr. Makarevych, 1950 & NST, L & NST (6), L (6), PL (1) \\
\hline KW33618 & Dnipropetrovsk reg. and distr. Hajova, 1960 & NST, L, PL & NST (2), L (5), PL (1) \\
\hline KW33628 & Volyn reg., Kamin-Kashirsk distr. Bradis, 1940 & $\mathrm{~L}, \mathrm{PL}$ & NST (1), L (2), PL (1) \\
\hline KW62763 & Ivano-Frankivsk reg., Verkhovina distr. Blum, 1978 & $\mathrm{~L}, \mathrm{PL}$ & NST (1), L (2), PL (1) \\
\hline
\end{tabular}

*NST - norstictic acid, L - lichesterinic acid, PL - protolichesterinic acid; ** content of substances indicated in brackets are: 1 - traces, $2-3-$ minor, $4-5-$ medium, 6-10-major.

examine the effects of environmental, geographical, chemical and morphological variables on the quantitative morphometric thallus parameters (such as width of the main and terminal branches, and size of the thalli), we performed an analysis of variance (ANOVA). Nominal variables included in ANOVA were: occurrence in one of the 13 populations and five natural zones of Ukraine, in three specific habitats, at four substrata and three classes of altitude above sea level (Table 2), the presence of norstictic acid detected by TLC and presence of isidioid projections (Table 3). Only values with high support are shown in Table 5 and discussed. The variables included in the PCA were: width of the main branch, width of the terminal branch and size of the thalli. The resulting PCA biplots were selected according to the maximum variance of projection along each component (Fig. 3).

To analyze the pairwise correlation between the presence and absence of norstictic acid and the geographical distance between $C$. aculeata specimens, we performed a Mantel test with 99 permutations, as implemented in Genalex (Peakall \& Smouse 2006; Fig. 4). In total, 256 specimens of the $C$. aculeata s. lat. analyzed by TLC (Table 2) were included in this study.

The distribution map for the $C$. aculeata s. lat. specimens studied was drawn in ArcGis.10 (http://www.esri. com/software/arcgis). The natural zonation of Ukraine follows Prydatko (1998; http://biomodel.info/trainingpackage/ukraine-nature-agricultural-zoning), and is shown in Fig. 1E.

\section{Results}

\section{Morphology}

We found a strong correlation between the size of thalli and the presence of isidioid projections (Fig. 2, Table 5). Thalli without isidioid projections were smaller than thalli with this trait. However, we found no clear regional differentiation in the frequency of isidioid projections. The percentage of specimens with isidioid projections varied greatly among populations $(0-100 \%$ of specimens per population, Table 3 ). While every specimen investigated in the populations of Antratsit and Chatyr Dag had isidioid projections, none of the specimens from Arabat Split Botanical Reserve had this characteristic (Table 3). 

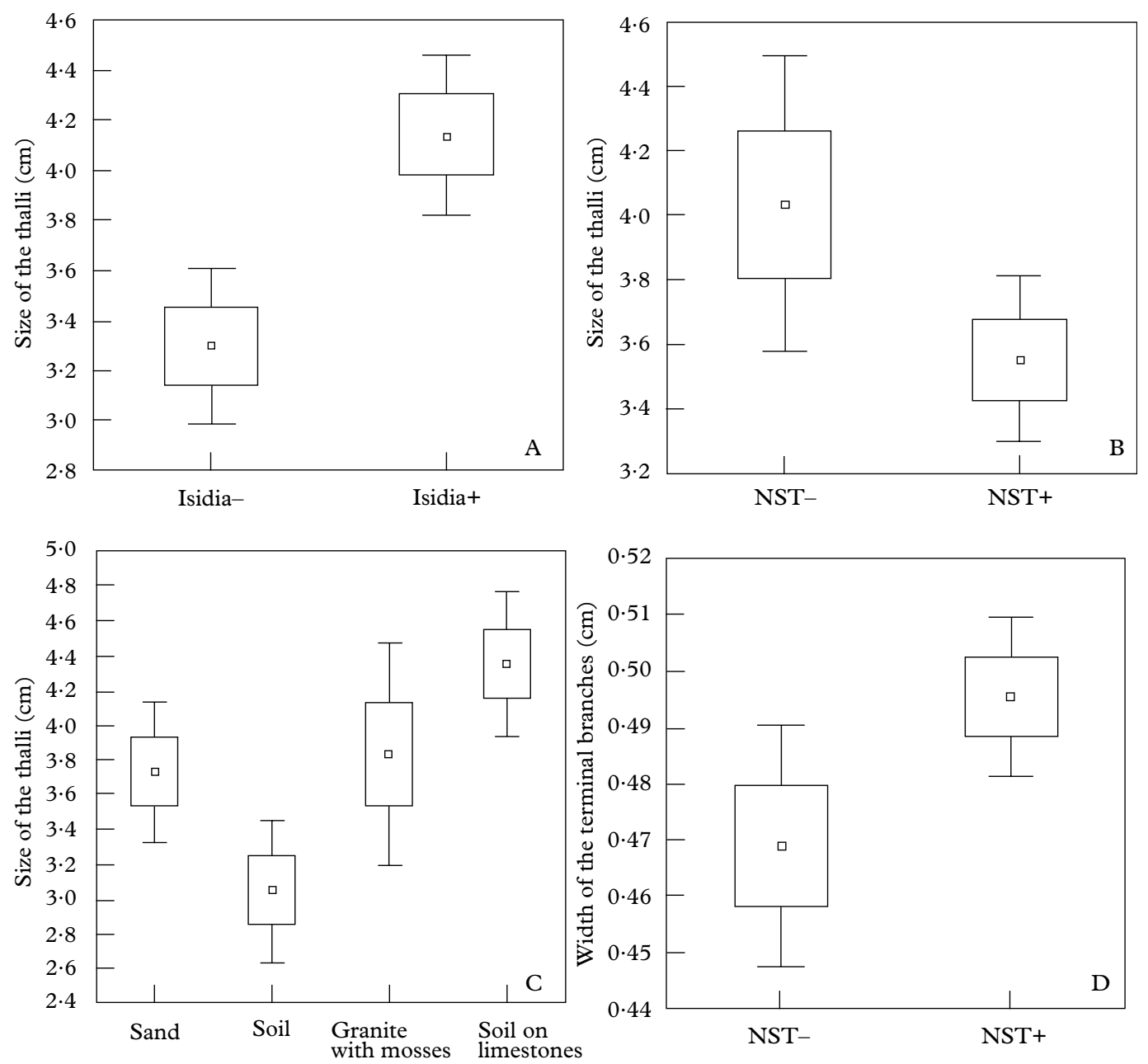

Mean; $\square$ Mean \pm SE; I Mean $\pm 0.95 \%$ confidence interval

FIg. 2. Relationships among the 122 specimens of Cetraria aculeata group between thallus size and presence or absence of isidioid projections ( $\mathrm{A}, t=-3.751, P=0.0003, \mathrm{df}=120$ ), presence or absence of norstictic acid $(\mathrm{B}, t=1.996, P=0.048, \mathrm{df}=74)$ and substratum groups $(\mathrm{C}, t=2 \cdot 222, P=0 \cdot 029, \mathrm{df}=76$ ), and between width of terminal branches and presence or absence of norstictic acid $(\mathrm{D}, t=-2 \cdot 146, P=0 \cdot 033, \mathrm{df}=120)$.

Our systematically sampled dataset revealed rather small differences in morphometric traits, that are essential for species identification, such as the width of the main and terminal branches or the size of the thalli (Table 3). The CV of these characteristics showed little or only average variation in the entire dataset, as well as within each population. How- ever, an ANOVA applied to the morphometric variables of $C$. aculeata s. lat. in relation to regional effects revealed significant differences between populations (Table 5). Continuous variation within the three morphometric characteristics analyzed was also confirmed by PCA (Fig. 3). The first two components (axes) of PCA explained $77 \cdot 8 \%$ 
TABLE 5. Results of an analysis of variance testing the effect of environmental, geographical and morphological variables on the morphometric parameters of Cetraria aculeata s. lat. individuals representing different parts of Ukraine (only significant values are shown, $\mathrm{n}=122$ ).

\begin{tabular}{|c|c|c|c|c|c|}
\hline Morphometric parameters & Source of variation & Sum of Squares & $\mathrm{df}$ & $F$ & $P$ \\
\hline Width of main branch & $\begin{array}{l}\text { Population } \\
\text { Substratum }\end{array}$ & $\begin{array}{l}1 \cdot 22 \\
0 \cdot 47\end{array}$ & $\begin{array}{l}4 \\
1\end{array}$ & $\begin{array}{l}4 \cdot 00 \\
6 \cdot 22\end{array}$ & $\begin{array}{l}0 \cdot 0046 \\
0 \cdot 0142\end{array}$ \\
\hline Width of terminal branch & Population & $0 \cdot 06$ & 4 & $3 \cdot 54$ & $0 \cdot 0094$ \\
\hline Size of the thalli & $\begin{array}{l}\text { Population } \\
\text { Isidia }\end{array}$ & $\begin{array}{r}41 \cdot 31 \\
6 \cdot 16\end{array}$ & $\begin{array}{l}4 \\
1\end{array}$ & $\begin{array}{r}10 \cdot 21 \\
6 \cdot 10\end{array}$ & $\begin{array}{r}<0.0001 \\
0.0152\end{array}$ \\
\hline
\end{tabular}

of variance (the two axes explained $43 \cdot 4 \%$ and $34.4 \%$ of the variance).

\section{Chemistry}

The analysis of the specimens by TLC showed that the presence of norstictic acid among the populations varied considerably (Table 3). Specimens distributed in the Forest zone of Ukraine and in the Carpathians always lacked norstictic acid (Table 3, Fig. 1E). Additionally, we detected lichesterinic and/or protolichesterinic acids in the medulla of some of the specimens, as have others in the literature (Kärnefelt 1986; Vainshtein et al. 1990). In contrast to the northern populations of $C$. aculeata s. lat., some of the specimens from the southern populations in the Steppe zone and the Crimean Mountains contained norstictic acid (17-100\% of specimens per population; Table 3).

HPLC revealed a very broad range of norstictic acid content in each specimen (Table 4). The specimens collected from the same localities contained very different quantities, and some had only traces which could not be detected by TLC. Surprisingly, traces of norstictic acid were detected by HPLC even in specimens from northern Ukraine and the Carpathians, where no norstictic acid was detected by TLC (Table 4). With HPLC we also detected traces of fumarprotocetraric and connorstictic acids in several specimens, which have never been reported before for C. aculeata s. lat. Rangiformic acid was mentioned once for $C$. aculeata from New Zealand (Galloway 1985), and occasionally minor amounts of nephrosterinic and isonephrosterinic acids have been detected by HPLC (Thell \& Kärnefelt 2011).

The analyzed specimens of $C$. aculeata s. lat. showed no reactions with spot and microcrystal tests. As a control, we tested spot reactions and conducted microcrystal tests with $\mathrm{K}$ and $\mathrm{Pd}$ to detect norstictic acid in other lichen species: Aspicilia cinerea (L.) Körb., Cladonia symphycarpia (Flörke) Fr. and Pleurosticta acetabulum (Neck.) Elix \& Lumbsch. These species developed red spots with $\mathrm{K}$ or $\mathrm{Pd}$ and displayed typical reddish crystals in the microcrystal tests. Therefore, we conclude that, in the case of Cetraria aculeata s. lat., spot reactions and the microcrystal test cannot be used to detect norstictic acid.

\section{Relationship between morphology, chemistry, geographical and environmental factors}

We found a significant correlation between thallus size and the presence of norstictic acid, as detected by TLC (Fig. 2). Samples containing norstictic acid were slightly smaller than samples where norstictic acid could not be detected by TLC. At the same time, specimens lacking norstictic acid had narrower terminal branches than specimens with norstictic acid (Fig. 2). Specimens growing on bare soil and sand had smaller thalli than specimens collected on granite or limestone outcrops (Fig. 2).

All three morphometric thallus variables differed between the populations of $C$. aculeata $\mathrm{s}$. lat. The width of the main thallus branch also depended on the substratum, 

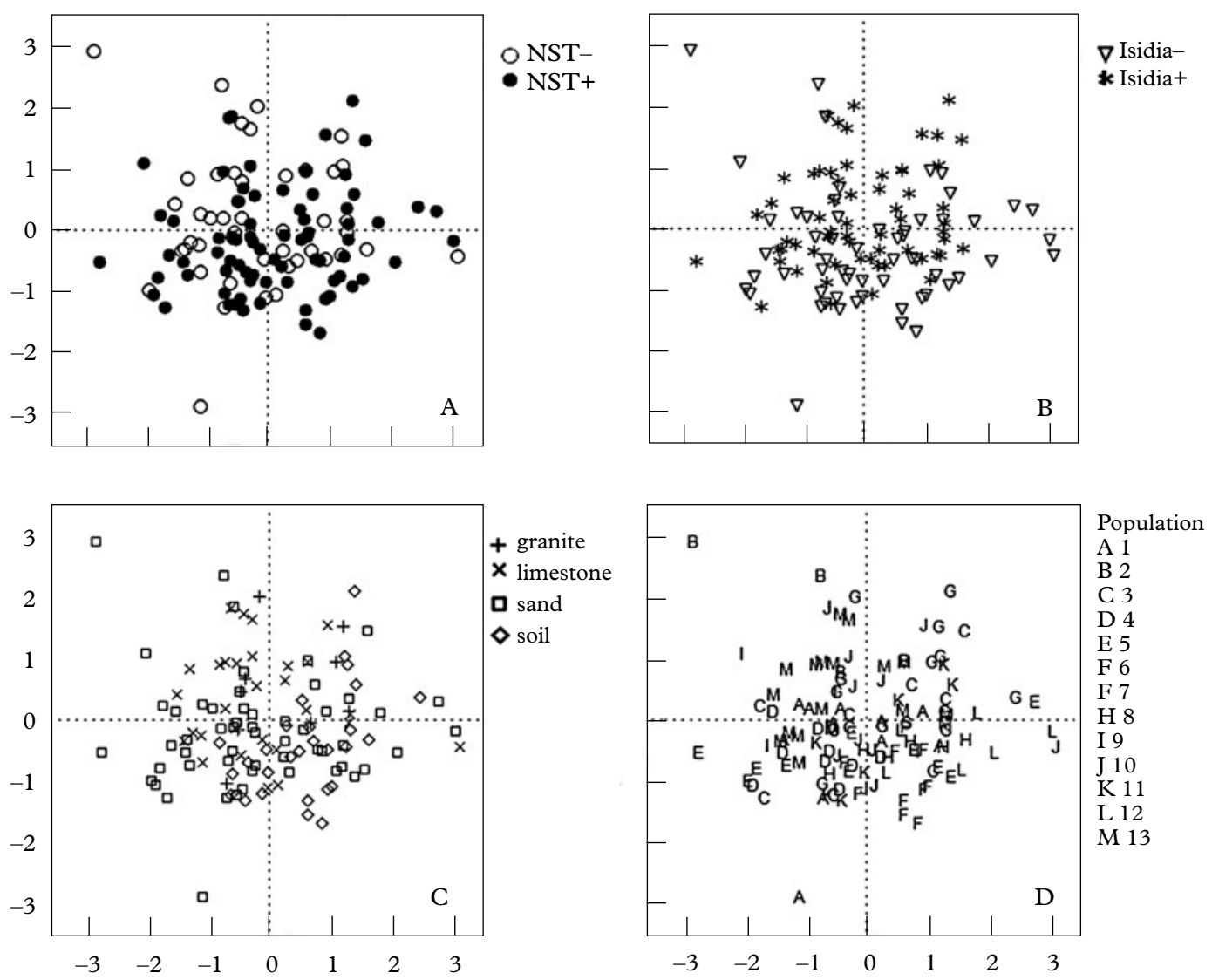

FIg. 3. PCA results based on the morphometric characteristics of the C. aculeata s. lat. in Ukraine, $n=122$. A, specimens differing chemically are shown; B, specimens with and without isidioid projections are marked; C, specimens preferring different substrata are distinguished; $\mathrm{D}$, specimens belonging to different populations are indicated.

and the presence of isidioid projections was correlated with thallus size (Table 5). No correlations were found between morphometric features and the five natural zones of Ukraine, the three specific habitats, or the three classes of altitude above sea level (Table 5).

A continuous scatter plot from a PCA of the morphometric features of the $C$. aculeata s. lat. specimens (Fig. 3) had no structure when compared to the presence of isidioid projections, norstictic acid content, substrata preference and sampling in different populations.

We found a weak positive correlation between the presence of norstictic acid and a large geographical distance up to $800 \mathrm{~km}$.
The overall linear fit of the Mantel test for geographical distance and chemical identity was $7 \cdot 015^{-7}(P<0 \cdot 001$, Fig. 4B), but only $5 \cdot 385^{-4}(P=0 \cdot 6$, Fig. 4A $)$ for short distances up to $50 \mathrm{~m}$.

\section{Discussion}

\section{Taxonomic status}

Our analyses of the morphological, chemical, ecological and geographical characteristics of $C$. aculeata s. lat. specimens, originating from 13 populations (Tables $2 \& 3$ ), showed a continuous variation in morphometric features, as well as in the presence of isidioid projections and norstictic acid. Differences 


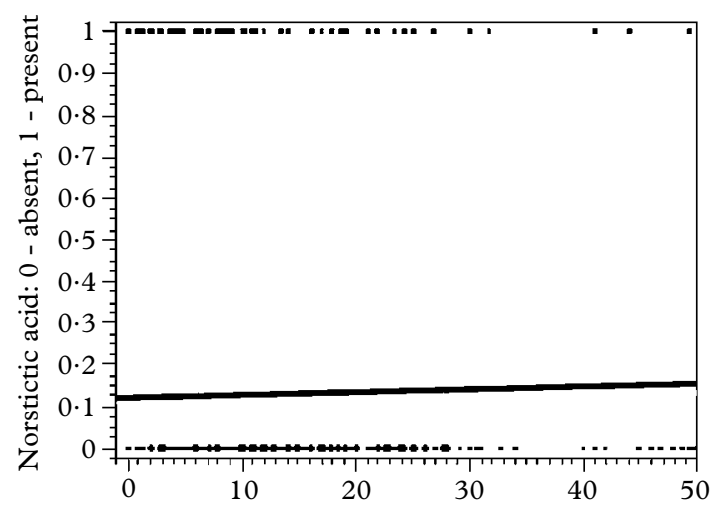

$$
\text { A }
$$

Distance (m)

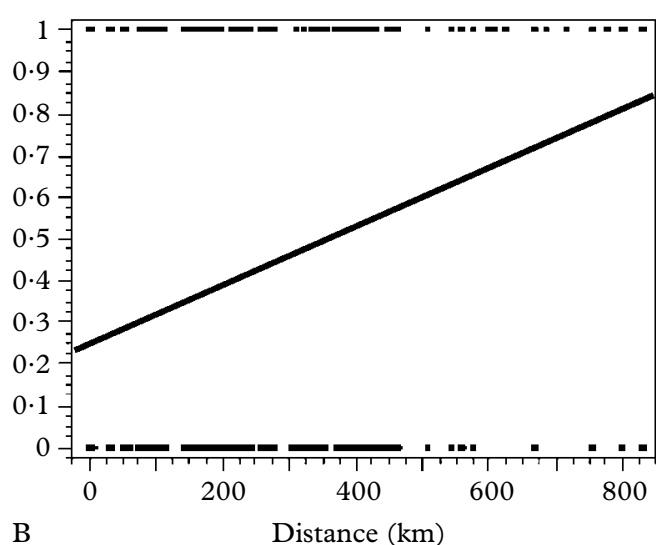

FIG. 4. Linear fit of Mantel test of geographical distance and chemical identity (absence or presence of norstictic acid) among pairs of specimens, $n=256$. A, small distances up to $50 \mathrm{~m}$, parameters estimated with a linear fit of $5 \cdot 385^{-4}, P<0 \cdot 6 ; \mathrm{B}$, large distances up to $800 \mathrm{~km}$, parameters estimated with a linear fit of $7 \cdot 015^{-7}, P<0 \cdot 001$.

between populations in the morphometric traits examined (Tables $3 \& 5$ ) explained local infraspecific variability and did not support subdivisions among the specimens of Cetraria aculeata s. lat. we studied (Fig. 3D).

Seven out of 13 populations were homogeneous in norstictic acid content when analyzed by TLC, while the other six populations contained chemically distinct individuals (Table 3). We found a general trend for specimens lacking norstictic acid to have larger thalli and narrower terminal branches (Fig. 2B \& D). Therefore the presence of norstictic acid depends on the size of the thallus, which reflects the ontogenetic stage, and thus should not be considered for taxonomic purposes. An analogous trend has been found for perlatolic and usnic acids in another terricolous lichen species, Cladonia stellaris (Opiz) Pouzar \& Vězda (Fahselt 1984). We hypothesize that norstictic acid biosynthesis is active during the early stages of thallus development, appearing shortly after thallus fragmentation, and declines or becomes deactivated later, once the thalli have reached a certain size. We may also speculate that norstictic acid plays an important role in the complexation with heavy metals occurring in the substratum, which would otherwise be toxic for the small thalli. The ability of lichen thalli to incorporate heavy metal ions into oxalates is well-known, and seems to be a way of coping with the effects of toxic elements (Jones \& Wilson 1985; Purvis 1996). Norstictic acid is also known to form complexes with other toxic metals, including copper (Purvis et al. 1987).

We found no correlation between the presence of norstictic acid and any of the environmental factors analyzed (Table 5), even though we expected specimens with norstictic acid (revealed by TLC) to prefer geographically different regions (according to Kärnefelt 1986) or to occur mainly on carbonaceous substrata (according to Hauck et al. 2010). The distribution pattern of norstictic acid in C. aculeata s. lat. did not correlate with the natural zones of Ukraine, habitats, substrata or different altitudinal levels. However, specimens with norstictic acid (TLC) were limited to southern regions in Ukraine (the forest-steppe, steppe zones, and the Crimean Mountains), where they co-occur with specimens lacking norstictic acid. In contrast, specimens without norstictic acid (TLC) grow throughout all of Ukraine (Table 3, Fig. 1E). The sporadic presence of specimens with norstictic acid in southern, but not northern, areas supports the hypothesis that norstictic acid plays an adaptive role in lichens growing in an arid climate (Hauck et al. 2010). A similar trend has been identified 
in the terricolous lichen Flavocetraria nivalis (L.) Kärnefelt \& A. Thell, which has higher concentrations of usnic acid in colder environments (Bjerke et al. 2004), and for the epiphytic Pseudevernia furfuracea (L.) Zopf, which contains olivetoric or physodic acids, depending on climate (Martellos 2003). These support Hale's theory (Hale 1956) that the synthesis of lichen secondary compounds is governed by climatic gradients. Nevertheless, several other studies have found no evidence for a climatic dependency of lichens secondary chemistry (Halvorsen \& Bendiksen 1982; Fahselt 1984).

Mantel tests revealed a significant spatial autocorrelation between the norstictic acid content (as detected by TLC) and the geographical distance between the individuals sampled (Fig. 4B). This reflects regional differences in norstictic acid content (as measured by HPLC) with only traces of norstictic acid (not detectable by TLC) in northern Ukraine and partly higher concentrations in the southern regions. However, we found no autocorrelation at local scales (Fig. 4A). This indicates that local habitat characteristics do not strongly influence the presence or absence of norstictic acid in $C$. aculeata s. lat. Pérez-Ortega et al. (2012) studied extreme cases of phenotypic plasticity in $C$. aculeata s. lat., including both distinctly vagrant specimens with thick thalli and 'typical' C. aculeata from the same habitats in Spain. These thick vagrant specimens did not contain norstictic acid and thus, according to Kärnefelt (1986), were classified as $C$. $a c u$ leata s. lat. (Pérez-Ortega et al. 2012). The study of Pérez-Ortega et al. (2012) revealed anatomical and physiological differences between the thick vagrant and 'typical' individuals of $C$. aculeata s. lat. from the same habitats. The authors found, however, shared haplotypes between those morphs and thus emphasized that the vagrant morphs are adaptations to aridity. We consider this as further evidence for the morpho/chemical variability within populations of $C$. aculeata s. lat. being due to ecologtical (microclimate) and not taxonomic reasons.

The recent worldwide multigene studies of Cetraria aculeata s. lat. populations (Fernández-
Mendoza et al. 2011; Fernández-Mendoza \& Printzen 2013; Printzen et al. 2013) ${ }^{1}$ revealed pleistocene diversification within the C. aculeata group into several genetic clusters. The only small population from Ukraine (Crimean Mountains) of five individuals with norstictic acid was included in the last two studies, and it appeared to be related to the Mediterranean phylogenetic clade. However, more extensive sampling of $C$. aculeata s. lat. from Ukraine, based on a subset of the specimens used in our study, revealed shared haplotypes with other genetic clusters, but no relationship between the genetic structures of populations with norstictic acid production (Lutsak et al. 2012).

Further evidence for the incomplete speciation within $C$. aculeata s. lat. comes from the gene flow between different phylogenetic clusters within $C$. aculeata (Fernández-Mendoza \& Printzen 2013), and shared haplotypes among different operational taxonomic units, such as $C$. steppae, C. crespoae and $C$. aculeata s. str. represented from geographically distinct areas (Printzen et al. 2013). The speciation seems to be very slow for taxa with vegetative reproduction only, where natural selection is determined by random mutations but not recombinations. Cetraria aculeata s. lat. includes several genetically distinct clades related to the phylogeographical history of the species (Fernández-Mendoza \& Printzen 2013; Printzen et al. 2013), but these do not correspond to secondary chemistry or morphological characteristics. Higher levels of norstictic acid production in C. aculeata s. lat. in southern Ukraine may be connected to the aridity of glacial permafrost (Hewitt 1999). Acid production seems to be selectively activated depending on the microclimate and the developmental stage of thalli.

Possible reasons for the chemical variation in $C$. aculeata s. lat. populations may be the large-scale geographical and climatic dependence of gene expression, photobiont switching and microbial inhabitants (Muggia et al.

\footnotetext{
${ }^{1}$ All representatives of $C$. aculeata group were pooled together and treated as " $C$. aculeata s. lat." in Printzen et al. (2013), but not in other studies.
} 
2009; Bates et al. 2011; Fernández-Mendoza et al. 2011; Hodkinson et al. 2012). In a recent study, Printzen et al. (2012) demonstrated that the composition of alphaproteobacterial communities in geographically distant populations of $C$. aculeata is affected by environmental factors, but no relationship between these communities and secondary metabolite production has so far been found.

Our results support a decision to merge $C$. steppae Savicz with $C$. aculeata (Schreb.) Fr. and to treat both names as synonyms. The features currently used for the delimitation at species level are not appropriate because the differences in the morphological features are too small, the presence and quantity of norstictic acid varies greatly, and the substrata and habitats occupied by lichens are very diverse. Cetraria steppae Savicz may be regarded as a chemotype only, reflecting an infraspecific variation, even though norstictic acid has been detected in the type material of C. steppae by both TLC and HPLC (Table 4). It is commonly accepted that variation in the concentrations of particular secondary lichen substances does not provide sufficient grounds for taxonomic differentiation (Hawksworth 1976; Elix \& Stocker-Wörgötter 2008). As a consequence, we recommend formally synonymizing $C$. steppae Savicz with $C$. aculeata (Schreb.) Fr.:

\section{Cetraria aculeata (Schreb.) Fr.}

Nov. Sched. Critic. Lich. 4: 32 (1826)._Lichen aculeatus Schreb., Spicil. Flor. Lipsiens. 125 (1771).

Cetraria steppae (Savicz) Kärnefelt, Bryologist 96: 400 (1993).-Coelocaulon steppae (Savicz) Barreno \& Vázquez, Lazaroa 3: 329 (1982). -Cornicularia steppae Savicz, Notul. Syst. Inst. Cryptog. Horti bot. Petropol. 3: 187 (1924); type: Ukraine, Askania-Nova, Kherson reg., 1924, Oxner (LE, lectotype!).

Coelocaulon stepposa (Mereschk.) S. Y. Kondr., Flora Lyshajnykiv Ukraini 2(2): 296 (1993)._Cetraria tenuissima f. stepposa Mereschk., Annals and Magaz. Nat. History 9(8): 249 (1921); type: Rossia meridio-orientalis, Tauria, Mereschkowsky (KAZ).

\section{Conservation status: Ukrainian case}

We suggest including Cetraria aculeata s. lat. in the next edition of the Red Data Book of Ukraine, which will replace the entry of $C$. steppae (Blum 1996; Blum et al. 2009). Including $C$. aculeata s. lat. in the Red Data Book will highlight the importance of conserving sand dunes in the Forest natural zone of Ukraine, as well as rock outcrops in the Crimean and Carpathian Mountains, where the species is even rarer than in the steppes. Cetraria aculeata already has an approved national conservation status in neighbouring areas (Lőkös \& Tóth 1996; Moutchnik \& Zavarzin 2005; Liška et al. 2008). Moreover, the other member of $C$. aculeata s. lat., which is difficult to designate in the field, is C. muricata (Printzen et al. 2013), a species that is also of conservation concern in neighbouring countries (Golubkov \& Kobzar 2005; Liška et al. 2008).

To assess the national threat category of C. aculeata s. lat., we took into consideration that the area of occupancy by this taxon in Ukraine has been constant during recent decades. Just two localities have disappeared due to habitat destruction in the Odessa and Kharkiv regions during the last 100 years (according to herbaria data from KW and KHER), which corresponds to $2 \cdot 4 \%$ of the total number of localities known for the taxon. However, the species inhabit vulnerable biotopes and recovery after disturbance is expected to be very slow because of vagrancy and the species' spatially limited vegetative reproduction (Heinken 1999).

We assessed the total national area of occupancy of $C$. aculeata s. lat. as nearly 0.136 $\mathrm{km}^{2}$ by adding: 1) the area of occupancy of 13 local populations (each covered very small patches of up to $1000 \mathrm{~m}^{2}$ ) equal to $0.013 \mathrm{~km}^{2}$, and 2) the area of occupancy of the other 123 localities known in Ukraine, as documented in herbaria (KW, KHER), which is equal to at least $0 \cdot 123 \mathrm{~km}^{2}$. Thus, the total national area of occupancy of $C$. aculeata s. lat. is considerably less than the $20 \mathrm{~km}^{2}$ recommended for the 'vulnerable' threat category (VU) according to criterion D2 of IUCN (IUCN Standards and Petitions Subcommittee 2011). Finally, the threat category of $C$. aculeata s. lat. in Ukraine is assessed as vulnerable (VU). This corresponds with the status of $C$. steppae in the current edition of the Red Data Book of Ukraine 
(Blum et al. 2009) and Russia (Golubkova et al. 2008).

We thank Prof. O.Ye. Khodosovtsev (Kherson) for valuable advice and for sending herbarium materials (KHER), as well as Prof. S.Ya. Kondratyuk (Kyiv), Prof. C. Printzen (Frankfurt on Main) and three anonymous referees for their useful comments. We are grateful to Prof. M. P. Andreev (Saint-Petersburg) for sending the type specimen (LE220); Prof. V.P. Heluta and O.V. Vasyluk (Kyiv) for sampling the Ratno and Antratsit populations; Dr. F. Fernández-Mendoza (Frankfurt on Main) for help with the sampling design for population study; Dr. L. Lőkös (Budapest), Dr. A. Senkandeşler (Izmir), Dr. A. Tsurikov (Homel), and Dr. A. Yatsina (Minsk) for providing several references; and Dr. S. Dingwall (Birmensdorf) for revising the English of the manuscript. We thank the Rufford SGF for partial funding of this study, as well as the Swiss State Secretariat for Education and Research (SER).

\section{REFERENCES}

Bates, S. T., Cropsey, G. W. G., Caporaso, G. J., Knight, R. \& Fierer, N. (2011) Bacterial communities associated with the lichen symbiosis. Applied and Environmental Microbiology 77: 1309-1314.

Bjerke, J. W., Joly, D., Nilsen, L. \& Brossard, T. (2004) Spatial trends in usnic acid concentrations of the lichen Flavocetraria nivalis along local climatic gradients in the Arctic (Kongsfjorden, Svalbard). Polar Biology 27: 409-417.

Blum, O. B. (1996) Lichen species have to be protected in Ukrainian flora. In Red Book of Ukraine: Plants (Y. R. Sheliag-Sosonko, ed.): 503-530. Kyiv: Ukrayinska Entsiklopedia [In Ukrainian].

Blum, O. B., Kondratyuk, S. Y. \& Khodosovtsev, O. Y. (2009) Lichens. In Red Book of Ukraine: Plants (Y. P. Didukh, ed.): 728-780. Kyiv: Globalconsulting [In Ukrainian].

Domaschke, S., Fernández-Mendoza, F., García, M. A., Martín, M. P. \& Printzen, C. (2012) Low genetic diversity in Antarctic populations of the lichen-forming ascomycete Cetraria aculeata and its photobiont. Polar Research 31: 1-13.

Elix, J. A. \& Stocker-Wörgötter, E. (2008) Biochemistry and secondary metabolites. In Lichen Biology. 2nd Ed (T. H. Nash III, ed.): 104-133. Cambridge: Cambridge University Press.

Fahselt, D. (1984) Interthalline variability in levels of lichen products within stands of Cladina stellaris. Bryologist 87: 50-56.

Fahselt, D. (2008) Individuals, populations and population ecology. In Lichen Biology. 2nd Ed (T. H. Nash III, ed.): 252-273. Cambridge: Cambridge University Press.

Fernández-Mendoza, F. \& Printzen, C. (2013) Pleistocene expansion of the bipolar lichen Cetraria aculeata into the Southern hemisphere. Molecular Ecology 22: 1961-1983.
Fernández-Mendoza, F., Domaschke, S., García, M. A., Jordan, P., Martín, M. P. \& Printzen, C. (2011) Population structure of mycobionts and photobionts of the widespread lichen Cetraria aculeata. Molecular Ecology 20: 1208-1232.

Galloway, D. J. (1985) Flora of New Zealand. Lichens. Wellington, New Zealand: Hasselberg.

Golubkov, V. V. \& Kobzar, N. N. (2005) Lichens. In Red Data Book of the Republic of Belarus: Plants (L. I. Khoruzhik, ed.): 355-383. Minsk: Belarusskaia Entsiklopedia imeni Petrusia Brovka [In Russian].

Golubkova, N. S., Dombrovskaia, A. V., Istomina, N. B., Makarova, I. I., Makryi, T. V., Muchnik, E. Ye., Pchelkin, A. V., Sedelnikova, N. V., Skirina, I. F., Tolpisheva, T. U. et al. (2008) Lichens. In Red Book of the Russian Federation: Plants and Fungi (Y. P. Trutnev, ed.): 703-752. Moskwa: Tovarishestvo nauchnyh izdanij KMK [In Russian].

Gupta,V. K., Darokar, M. P., Shanker, K., Negi, A., Shrivastava, S. K., Gupta, M. M. \& Khanuja, S. P. S. (2007) Rapid and sensitive HPLC method for the determination of polyphenols in various lichen species of Himalayan origin. Fournal of Liquid Chromatography and Related Technologies 30: 97-111.

Hale, M. E. (1956) Chemical strains of the lichen Parmelia furfuracea. American fournal of Botany 43: 456-459.

Halvorsen, R. \& Bendiksen, E. (1982) The chemical variation of Pseudevernia furfuracea in Norway. Nordic Fournal of Botany 2: 371-380.

Hauck, M., Jürgens, S.-R. \& Leuschner, C. (2010) Norstictic acid: correlations between its physicochemical characteristics and ecological preferences of lichens producing this depsidone. Environmental and Experimental Botany 68: 309-313.

Hawksworth, D. L. (1976) Lichen chemotaxonomy. In Lichenology: Progress and Problems (D. H. Brown, D. L. Hawksworth \& R. H. Bailey, eds): 139-184. London: Academic Press.

Heinken, T. (1999) Dispersal patterns of terricolous lichens by thallus fragments. Lichenologist 31: 603612 .

Hewitt, G. M. (1999) Post-glacial re-colonization of European biota. Biological fournal of the Linnean Society 68: 87-112.

Hodkinson, B. P., Gottel, N. R., Schadt, C. W. \& Lutzoni, F. (2012) Photoautotrophic symbiont and geography are major factors affecting highly structured and diverse bacterial communities in the lichen microbiome. Environmental Microbiology 14: 147-161.

IUCN Standards and Petitions Subcommittee (2011) Guidelines for Using the IUCN Red List Categories and Criteria. Version 9.0. Prepared by the Standards and Petitions Subcommittee. Online access: http://www.iucnredlist.org/documents/ RedListGuidelines.pdf

John, V. (1999) Lichenes Anatolici Exsiccati. Fasc. 1-3 (no. 1-75). Arnoldia 16: 1-44.

John, V. \& Breuss, O. (2004) Flechten der Östlichen Schwarzmeer-Region in der Türkei. Herzogia 17: 137-155. 
Jones, D. \& Wilson, M. J. (1985) Chemical activity of lichens on mineral surfaces - a review. International Biodeterioration 21: 99-104.

Kärnefelt, I. (1986) The genera Bryocaulon, Coelocaulon and Cornicularia and formerly associated taxa. Opera Botanica 86: 1-90.

Kärnefelt, I., Mattsson, J.-E. \& Thell, A. (1992) Evolution and phylogeny of cetrarioid lichens. Plant Systematics and Evolution 183: 113-160.

Kärnefelt, I., Mattsson, J.-E. \& Thell, A. (1993) The lichen genera Arctocetraria, Cetraria, and Cetrariella (Parmeliaceae) and their presumed evolutionary affinities. Bryologist 96: 394-404.

Liška, J., Palice, Z. \& Slavíková, Š. (2008) Checklist and Red List of lichens of the Czech Republic. Preslia 80: $151-182$.

Llimona, X. \& Hladun, N. L. (2001) Checklist of the lichens and lichenicolous fungi of the Iberian Peninsula and Balearic Islands. Bocconea 14: 1-581.

Lőkös, L. \& Tóth, E. (1996) Red list of lichens of Hungary (a proposal). In Proceedings of the "Research, Conservation, Management” Conference (E. Tóth \& R. Horváth, eds): 337-343. Aggtelek, Hungary: Aggtelek National Park Directorate.

Lutsak, T., Fernández-Mendoza, F., Nadyeina, O., Pérez-Ortega, S. \& Printzen, C. (2012) Cetraria steppae: a lichen species of central Asian steppes, or part of a wider Mediterranean clade of $C$. aculeata? In Abstracts of the 21st International Symposium "Biodiversity and Evolutionary Biology" of the German Botanical Society (DBG), 16-19 September, 2012, Mainz, Germany, p. 126.

Manojlović, N. T., Vasiljević, P., Jusković, M., Najman, S., Janković, S. \& Milenković-Andjelković, A. (2010) HPLC analysis and cytotoxic potential of extracts from the lichen, Thamnolia vermicularis var. subuliformis. Fournal of Medicinal Plants Research 4: 817-823.

Martellos, S. (2003) The distribution of the two chemical varieties of the lichen Pseudevernia furfuracea in Italy. Plant Biosystems 137: 29-34.

Mereschkowsky, C. (1921) Diagnoses of some lichens. Annals and Magazine of Natural History 9: 249.

Moutchnik, E. \& Zavarzin, A. (2005) Lichens in the Red Data Books in Russia. Folia Cryptogamica Estonica 41: 59-80.

Muggia, L., Schmitt, I. \& Grube, M. (2009) Lichens as treasure chests of natural products. Sim News 59: 85-97.

Orange, A., James, P. W. \& White, F. J. (2001) Microchemical Methods for the Identification of Lichens. London: British Lichen Society.

Oxner, A. M. (1937) Handbook of the Lichens of Ukrainian Republic. Kyiv: Vydavnytstvo AN URSR [In Ukrainian].

Oxner, A. M. (ed.) (1993) Flora of the Lichens of Ukraine. Vol. 2. Kyiv: Naukova Dumka [In Ukrainian].

Peakall, R. \& Smouse, P. E. (2006) GenAlEx 6: genetic analysis in Excel. Population genetic software for teaching and research. Molecular Ecology Notes 6: 288-295.
Pérez-Ortega, S., Fernández-Mendoza, F., Raggio, J., Vivas, M., Ascaso, C., Sancho, L. G., Printzen, C. \& de los Ríos, A. (2012) Phenotypic plasticity in lichens: insights on the biology of extreme modifications in Cetraria aculeata (lichenized Ascomycota). Annals of Botany 109: 1133-1148.

Poelt, J. (1969) Bestimmungsschlüssel Europäischer Flechten. Lehre: Verlag J. Cramer.

Printzen, C., Fernández-Mendoza, F., Muggia, L., Berg, G. \& Grube, M. (2012) Alphaproteobacterial communities in geographically distant populations of the lichen Cetraria aculeata. FEMS Microbiology Ecology 82: 316-325.

Printzen, C., Domaschke, S., Fernández-Mendoza, F. \& Pérez-Ortega, S. (2013) Biogeography and ecology of Cetraria aculeata, a widely distributed lichen with a bipolar distribution. MycoKeys 6: 33-53.

Prydatko, V. (ed.) (1998) Nature-Agricultural Zoning of Ukraine. Kyiv: GUGKK.

Purvis, O. W. (1996) Interactions of lichens with metals. Science Progress 79: 283-309.

Purvis, O. W., Elix, J. A., Broomhead, J. A. \& Jones, G. C. (1987) The occurrence of copper-norstictic acid in lichens from cupriferous substrata. Lichenologist 19: 193-203.

Randlane, T. \& Saag, A. (2006) Cetrarioid lichens in Europe - an identification key for the species. In Central European Lichens - Diversity and Threat (A. Lackovičova, A. Guttova, E. Lisicka \& P. Lizoň, eds): 75-84. Ithaca: Mycotaxon Ltd.

Savicz, V. P. (1924) De lichene terrestri novo Cormicularia steppae mihi nec non lichene Cornicularia tenuissima. Notulae Systematicae ex Instituto Cryptogamico Horti Botanici Petropol. 3: 185-188 [In Russian].

Seaward, M. R. D., Sipman, H. J. M. \& Sohrabi, M. (2008) A revised checklist of lichenized, lichenicolous and allied fungi for Iran. Sauteria 15: 459-520.

Sohrabi, M. \& Alstrup, V. (2007) Additions to the lichen mycota of Iran from East Azerbaijan Province. $M y$ cotaxon 100: 145-148.

Thell, A. \& Kärnefelt, I. (2011) Cetraria. Nordic Lichen Flora 4: 37-43.

Thell, A., Stenroos, S. \& Myllys, L. (2000) A DNAstudy of the Cetraria aculeata and $C$. islandica groups. Folia Cryptogamica Estonica 32: 95-106.

Thell, A., Stenroos, S., Feuerer, T., Kärnefelt, I., Myllys, L. \& Hyvönen, J. (2002) Phylogeny of cetrarioid lichens (Parmeliaceae) inferred from ITS and btubulin sequences, morphology, anatomy and secondary chemistry. Mycological Progress 1: 335-354.

Urbanavichus, G. P. (2010) A Checklist of the Lichen Flora of Russia. St. Petersburg: Nauka.

Vainshtein, E. A., Ravinskaia, A. P. \& Shapiro, I. A. (1990) Handbook on Lichen Chemotaxonomy: Methodological Guide. Leningrad: Nauka [In Russian].

Wagner, V. \& Spribille, T. (2005) Preliminary Checklist of Lichens of Kazakhstan. Online access: http:// www.geobotanik.uni-goettingen.de/spribille/

White, F. J. \& James, P. W. (1985) A new guide to microchemical techniques for the identification of lichen substances. Bulletin of the British Lichen Society 57: 1-41. 
Yazıc1, K., Aptroot, A., Aslan, A., Etayo, J., Spier, L. \& Karagöz Y. (2010) Lichenized and lichenicolous fungi from nine different areas in Turkey. Mycotaxon 111: 113-116.

Yoshimura, I., Kinoshita, Y., Yamamoto, Y., Hunecks, S. \& Yamadan, Y. (1994) Analysis of secondary metabolites from lichen by high performance liquid chromatography with a photodiode array detector. Phytochemical Analysis 5: 197-205.

Zhurbenko, M. P. (1996) Cetraria Ach. emend. Kärnef. In Handbook of the Lichens of Russia. Vol. 6. Alectoriaceae, Parmeliaceae, Stereocaulaceae (N. S. Golubkova, ed.): 41-44. St-Petersburg: Nauka [In Russian]. 